\title{
Evaluation of Risk Elements In Real Estate investment In Nigeria: The Case Of Uyo Metropolis, Akwa Ibom State
}

\author{
Dr. Francis P. Udoudoh, Department of Estate Management, \\ University of Uyo, Nigeria \\ Dr. Usen P. Udoh, Department of Architecture, University of Uyo, Nigeria*
}

\begin{abstract}
Risk is a common feature of all forms of investment including real estate which involves the creation of new income yielding assets from land and its resources based on capital analysis of expected costs and benefits within a given time. While some real estate investments have a high-risk profile, others have low-risk profile depending on the type, location and lease term. This study was designed to evaluate the different elements of risk in relation to different stages of real estate development in Uyo Metropolis, Akwa Ibom State. A total of 200 project sites were randomly selected and visited for data collection. Accordingly, 200 sets of questionnaire containing items bordering on types of risk/ project development were administered to the private estate developers while simple percentages was employed to analyse data. Findings indicated that the nature of risk encountered by investors varied according to the stages of project development, especially during preparation of development plans and building construction. Majority of respondents identified lack of access to project finance, delay in issuance of $C$-of- $O$ and default in rent payment as the major risk elements in their investment. Based on these findings, it was recommended that real estate investors and managers should evolve effective and efficient management strategies to mitigate dominant risk elements for enhanced investment opportunity in the real sector.
\end{abstract}

\section{Introduction}

The term risk has been defined as the probability of loss of income, assets or condition of mishap, unfortunate situation or circumstances that result in the decline of revenue or loss of income, property, wealth and other items having economic and financial values. In statistics, risk relates to a situation where a probability or weight can be assigned to a possible outcome arising from a policy decision (Enever and Isaac,1997). In the financial sense, risk is somewhat more intricate than the calculation of historical or expected returns. It is the possibility that an investor will lose some or all of the initial investment. Such conditions are the outcomes of a fall in product demand, high competitive pressure, unfavourable government policies, poor economic conditions, community uprising,industrial disharmony and management inefficiencies. Environmental factors such as changing weather conditions and environmental degradation are also noted to have adverse effect on investment. The international component of risk is relatively more complex, which arises from divergent economic policies, political and cultural ideologies thus making management of risk across national boundaries a difficult task.

From the real estate investment perspective, risk is seen as the level of probability that a required return will be achieved when measured in terms of capital value and income. As an investment, some properties have a high-risk profile while others have low-risk profile. This depends on the type, nature, location and possibly, the lease term of the property. Over time, the variance of actual return from expected return can be measured and used to help determine probability level. Risk is a deviation from the expected return and not just the chance that the return on an investment will be below expectations (Geddes, 2002). Thus, risk is about the interaction of future returns, which can have a number of possible results, and the chances that any particular outcome will occur. It is all about variances and probabilities. The degree to which actual performance may exceed the expected performance is called the upside potential while the amount by which it falls below expectation is known as the downside risk. Investors are concerned with the upward potentials, particularly when the investment is funded by borrowed capital. Upward potential is the actual bonus over and above the targeted return (Dubben and Sayce, 1991).

Risk is a common feature of all forms of investment including real estate and fundamental to investment choice. Therefore, any investor who embarks on a project development or acquires a property expects some benefits as future returns.Like any other form of investment,real estate has two principal components: expected return and risk. In an ideal situation, an investor is expected to maximize returns while minimizing risk.Therefore, the investor assumes risk with the hope of making profit or other forms of return. Risk assumption depends onpast investment operation, future projection, trend in the economy, government intervention programmes and the expected returns from the investment. Often, the actual returns from the investment may vary from the projected returns. In some cases, the invested capital is lost. According to Ubom 
(2010), the degree of variability of the actual return from the estimated return of the investment as well as the probability of the loss of capital reflects the risk elements of investment. The higher the degree of such variability, the higher the risk involved and vice versa; and the greater the risk involved in a project, the greater the expected rate of return or cost of capital. The problems associated with investment risk cannot be totally eliminated even in an ideal economic situation.

Real estate investors come across various types of risk in the course of embarking on projects and in the life of the projects. Investment risk may be examined on the basis of the fundamental components or sources of risk and making predictions on how future returns will be affected by each fundamental risk. Risks have been variously classified into business, financial, interest rate,market and business power risks. Other forms of risk are political risk, tenant risk, sector risk, structural risk, taxation risk, planning risk, legal risk, comparative risk, timing risk and holding period risk, risk of unplanned obsolescence as well as management or union risk (Bowlinet al., 1980; Okafor, 1983; Messner, 1984; Dubben and Sayce, 1991;Ajayi, 1998; Geddes, 2002; Chandra, 2010; and Udoudoh, 2016). These risks are collectively described as investment risk. The goal of an ideal investor is to embark on any project or scheme that involves minimum risk with an expectation of maximum profit.

In Akwa Ibom State where this study is based, there has been phenomenal growth in real estate investment especially in Uyo Metropolis - the Capital City -due to the influx of people and investors from other parts of the country as well as the ongoing renaissance in infrastructural development. There is therefore the need to empirically examine the risk structure/ components associated with real estate development in the area in order to generate a roadmap that would guide prospective investors in the real sector.

\section{Aim And Objectives Of Study}

The primary aim of this study is to assess those elements of risk that are of importance to a real estate investor. The objectives of the study included:

1. To examine the various forms of investment available to the real estate investor in Nigeria.

2. To identify the qualities expected from an investment that is attractive to the investor.

3. Tohighlight the various stages of real estate development.

4. To examine the different elements of risk in relation to the various stages of real estate development.

\subsection{Real Estate Investment}

\section{Literature Review}

Real estate has to do with land and buildings which is often referred to simply as property or landed property. According to Barlowe (1978), the concept of land as property involves real estate and has legal connotations. The legal connotations are concerned with the traditional and/ or modern-day constitutional rights bestowed on individuals, families, communities or the states to own, develop and manage land and its resources without hindering the rights of others. The rights are granted to private or public institutions to utilize land efficiently.Land means different things to different people. It includes all the physical development carried out by man on the earth's surface.These are man-made improvements onlandused to attain economic goals through the application of capital, labour and technology. It covers all economic crops and trees, buildings, structures and installations, roads, bridges, dams and all sorts of physical development on land. Agricultural resources include the fertile farmlands where economic crops, trees and vegetables are cultivated and arable farmlands used for cattle rearing. Economic trees include cocoa, rubber, cotton, oil palm, cowpea, maize, yam, fruits, vegetables and cassava; while livestock include cattle, goat, sheep, exotic poultry and local fowls.Residential land includes the various houses that are built for the occupation of individuals and members of the family. It may be tenement houses, flats, bungalows, maisonettes and multi-storey apartment blocks. Residential land is classified into high density, medium and low density residential areas within a residential estate, and is usually the largest use of land within the urban areas as well as privately or publicly built as permanent or semipermanent structures.

Commercial land includes shops and offices occupied for the purpose of carrying on any trade or profession in the expectation of profit. They may be converted or purpose-built like the shopping centres of UAC Trading Company found in Nigerian major cities. It also includes the traditional markets, lock-up market complexes, motels and hotels, cinema houses, petrol/filling stations and supermarkets. Industrial sites include factories where production, processing and storing of raw materials and finished goods are done. The range of properties to be considered is extensive and varies from shops to residential properties converted for use as storage or for factory purposes, to well-constructed and lighted up-to-date promises with many amenities. The light industries may be located within the residential areas while heavy industrial outlets noted for industrial pollution are located at the outskirts of the city. Examples include petro-chemical industries and refineries.Educational sites are properties developed for the training and acquisition of knowledge and skills which may be privately or publicly owned. They include nursery/primary schools, secondary schools, technical 
colleges, higher institutions of learning such as Colleges of Education, Agriculture, Technology, Polytechnics and Universities found at nooks and crannies of Nigeria. Enever and Isaac (1997) see investment as the giving up of capital sums now in exchange for benefits to be derived in the future, while Ajayi (2010) defined investment as an act of laying out money now in return for future financial rewards. Both look at returns on investment to accrue in financial form. Investment involves opportunity cost as the present consumption is foregone for the expected benefits. In total agreement with these scholars, an investment is the art of committing a given sum of money at the present time in expectation of future returns. It is the foregoing of a fixed sum as an alternative for some future benefits. Such benefits may be in the form of economic attainment such as income flow and/or capital gain, political power or philanthropic services. A decision as to the type of investment one can undertake depends on factors such as capital to be sunk into the business, feasibility and viability appraisal conducted, managerial skill, risk involvement and market forces.

Real estate investment involves the creation of new income yielding assets from land and its resources based on capital analysis of expected cost, risk and benefits within a given time. An investor may purchase a freehold or leasehold interest in landed property for any purpose through auction, tender, private treaty or bid. If the investment is an owner-occupied property or cultivated farmland, the returns could come in form of savings or food consumption for the family. The money that would otherwise have been used for payment of rent or purchase of foodstuff is saved after all.Investment decisions are influenced by various motives and usually require the comparison of alternative investment media such as real estate, bank deposits, gilts and equities. Whatever the nature of investment, a rational investor seeks to maximize his returns while minimizing the risk undertaken as has already been stated. Investment in landed property is inflation-proof, that is, it performs well even in the face of inflation as against those in bank deposits and fixed interest securities which are inflationprone.

\subsection{Forms Of Real Estate Investment}

These refer to all the options any potential real estate investor has in committing his resources in expectation of future benefits. Before embarking on any type of investment, certain qualities are expected from an investment that is attractive to the investor.Investment decisions are influenced by various motives. Some investors spend huge amount of money to establish a business where they sit as the Chief Executive Officers (CEOs) while others do so for the pecuniary motive of earning returns, both of which invariably represents the reward for undertaking such investment. Whatever the nature of investment, a rational investor seeks to maximize his returns while minimizing the risk undertaken. To earn reasonable returns, a prudent investor has to bear some risks which are determined through various ownership strategies. The various forms of real estate investment are categorized as follows:

(i) Construction: These include buildings constructed for various purposes including residential, commercial, industrial, and recreational, among others. The development process involves acquisition of suitable sites, formalization of relevant title documents, construction for occupation or letting, and management of the developed estate. According to Emoh (2004), almost any works to a property or change in management or use of premises can have the effect of modifying its usefulness and hence its income-earning capacity to the investor.

(ii) Acquisition: This involves acquisition of a freehold or leasehold interest in a developed property. This transaction enables the initial developer to realize the capital invested on an existing development for some other ventures. It has become a common trend by politicians, senior government officials and top business tycoons in major urban centres in Nigeria. Real estate investors, like other investors in stocksand shares, seek the highest rate of returns on their capital. In some transactions, they may accept a low initial yield because of the expectation of future growth of the investment. However, the yield is a reflection of thelevel of risk inherent in the investment.

(iii) Mortgage Transaction: This is a transaction where investors relinquish their interests in real estate in order to obtain some credit facilities. The interest held in the property serves as collateral for the borrowed funds. Redemption is at the amortization or full discharge of the principal and accruable interest thereof. Mortgage transaction is the most important single source of funding property development in the developed world. The establishment of mortgage institutions in Nigeria for this purpose is a welcome development. It creates avenue for potential investors to raise funds for physical development purposes.

(iv) Sales and Leaseback Transaction:This arises because an owner-occupier wishes to raise capital for a certain purpose and in the cause of doing this he decides to dispose off his property to somebody (corporate or private) on an arrangement that the lessor immediately leases the entire property or part of it back to him, the lessee. The lessee then occupies the property as an inferior interest holder (tenant) rather than as the owner, and is able to invest the capital in the business.

(v) Shares Acquisition: This involves the acquisition of shares in the companies involved largely in real estate transactions. Purchasing shares in a property company enables the investor to have a share in the returns 
arising from any development, expansion and management of property values arising thereof. Property company shares also tend to have high levels of volatility. According to Dubben and Sayce (1991), this is largely because many property companies have high borrowing and gearing capacities thereby making their profits particularly susceptible to economic and market changes.

\section{Methodology}

The study was based in Uyo Metropolis, the capital of Akwa Ibom State, Nigeria. Uyo is unarguably one of the most peaceful and rapidly growing cities in Nigeria. It is located on Latitude $5^{\circ} 3$ ' 0 " Northof the Equator and Longitude $7^{\circ} 56^{\prime}$ " " East of the Greenwich Meridian. According to the 2006 national population census report, Uyo had a total population of 309,573 which with a projected growth rate of $3 \%$ presently stands at about 559,123.During the field exercise, various project sites were visited, particularly those embarked upon by private individuals in Uyo, the capital city of Akwa Ibom State in South-South Region of Nigeria. These sites were chosen within the boundaries and enclaved by AtikuAbubakar Avenue, Abak Road and Idoro Road. This happens to be a new residential area within Uyo Urban that has been recently opened up and private real estate developers are acquiring virgin lands for development. Apart from the mentioned major roads that served as the boundaries to the neighbourhood, almost all the internal roads within are untarred and hence, not motorableduring rainy season after heavy rain downpour. Equally, the area has not been blessed withbasic urban infrastructure such as pipe-borne water and electricity supply from public mains. However, the residents are making frantic efforts to provide water through development of private boreholes and generators to provide electricity.

In order to gather adequate data for the research, a total of 200 questionnaires were produced and administered to private real estate developers in the study area. Random sampling method was adopted in the administration of questionnaire where twelve (12) items were presented for respondents to bare their opinions. Out of the 200 questionnaire, 188 of which representing $94 \%$ of the sampled size were properly completed and returned to the researchers within the stipulated timeframe. This response rate was found adequate for the research. Data analysis and presentation was done using tables and simple percentages.

\section{Data Presentation/ Discussion Of Findings}

This section highlights the major findings and discussions emanating from the field data collection.

\subsection{Stages In Real Estate Investment And Associated Risks}

Investments in real estate are confronted by various forms of risk.These risks, though varied, depend on location and type of the property, state of technology and financial position of the developers.Investmentoutcomesare also influenced by economic pressure, growth in population, people's taste and fashion, environmental and changing weather conditions. For instance, investment in real estate are restricted and controlled by various government agencies. The planning law stipulates the nature of development one can embark upon in a particular layout or street; the standard, height, width and occupancy ratio are also under control. Table 1 contains information on the various stages of real estate development and their associated risks as obtained from respondents.

Table 1:Stages Of Real Estate Development

\begin{tabular}{|l|l|l|l|}
\hline S/N & STAGES OF DEVELOPMENT & ACTIVITIES & ASSOCIATED RISK \\
\hline 1 & Site Acquisition & Scouting for suitable site & $\begin{array}{l}\text { i) Ascertaining the actual land owner } \\
\text { ii) Risk of being duped by agents/ } \\
\text { scouts } \\
\text { iii)Accessibility to the site }\end{array}$ \\
\hline 2 & $\begin{array}{l}\text { Preparation of Development } \\
\text { Plans }\end{array}$ & $\begin{array}{l}\text { i) Land surveying } \\
\text { ii) Issuance of C-of-O } \\
\text { iii)Approval of building plans } \\
\text { iv) Preparation of building plans }\end{array}$ & $\begin{array}{l}\text { i) High cost of surveying } \\
\text { ii) Delay in issuance of C-of-O } \\
\text { iii)Ability of contractors to interpret } \\
\text { the building plans }\end{array}$ \\
\hline 3 & Sourcing of Finance & $\begin{array}{l}\text { Consulting mortgage/ financial } \\
\text { institutions for funding }\end{array}$ & $\begin{array}{l}\text { Problem of meeting stipulated } \\
\text { collateralrequirements }\end{array}$ \\
\hline 4 & Building Construction & $\begin{array}{l}\text { i) Excavation and provision } \\
\text { foundation } \\
\text { ii)Blockwork, Slab and Roofing } \\
\text { iii)Finishing }\end{array}$ & $\begin{array}{l}\text { i) Adherence to plans specifications } \\
\text { ii) Uncertainty in prices of building } \\
\text { materials } \\
\text { iii)Use of inferior building materials }\end{array}$ \\
\hline 5 & $\begin{array}{l}\text { Provision } \\
\text { Infrastructure of }\end{array}$ & $\begin{array}{l}\text { Provision of access roads, electricity, } \\
\text { water and security at site }\end{array}$ & $\begin{array}{l}\text { i) Lack of accessibility to project site, } \\
\text { water, electricity and security at site } \\
\text { resulting in high cost of development }\end{array}$ \\
\hline 6 & Estate Management & $\begin{array}{l}\text { i) Letting and Leasing } \\
\text { ii)Estate maintenance } \\
\text { iii) Rent collection }\end{array}$ & $\begin{array}{l}\text { i) Selection of tenants } \\
\text { ii)Default in maintenance } \\
\text { iii)Default in rent payment }\end{array}$
\end{tabular}


Real estate development commences with sourcing and acquisition of a suitable piece of land for the envisaged project. The major risk facing investors at this stage is their inability to knowfor certain the actual land owners to avoid being duped by fake land owners. Where an intending developer is able to acquire a suitable piece of land, there exist theproblems of securing a clean title to such land in many instances. Where the vendor and the vendee had completed the purchaseagreement, produced survey plan with Certificate of Deposit, the problem of securing a statutory or customary right of occupancy has been most difficult in some states of Nigeria. It is either delayed in the Ministry of Lands and Urban Development or Local Government Councils in the case of customary right of occupancy or by the State Governor in the case of statutory right of occupancy for several months or years.All these culminate into delay in commencement of the envisaged project by the real estate investor.

Finance is the bane of any meaningful development and real estate requires huge capital outlay. With the high cost of land and building materials, it has become very difficult for many Nigerians to secure adequate funds to embark on any development. A resort to credit facility from themortgage banksand/or any financial institutions thus becomesthe best alternative. To be eligible to secure such facility, the investor is required to show evidence of landed property as collateral and where the loan is to be granted, it is at a very high interest rate. The changes in interest rate have a bearing on the welfare of investors (Chandra, 2010). The stringent conditions attached to the loan facilities havetactically disqualified many would-be developers from such financial leverages; while high and changing interest rates have brought about default or untimely repayment by the few beneficiaries. There is also the risk of uncertainty in prices of building materials in relation to the estimated total construction cost as contained in the bill of quantities.

The quality of real estate development in any urban centre is an index of the people standard of living. The major risks encountered by investors here include inability of contractors to interpret the approved building plans accurately and build to specifications, and the use of inferior building materials which do not enhance sustainable development. Many development sites are confronted with the problem of inaccessibility, lack of basic estate infrastructure such as electricity and water from public mains, and safety of the building materials on project sites. These constitute serious risk to real estate investors in the study area.The last stage of real estate development requires strategic management to attain the goal of setting up the estate. At this point, the investor is faced with problems of selection of responsible tenants who will keep to the lease agreement, such as payment of rent when due and maintaining the estate to enhance sustainability. These are necessary as default in rent paymentand lack of maintenance constitutes serious risks to real estate investors.

\subsection{Risk Elements In Real Estate Investment}

Before embarking on any type of investment, certain qualities are expected from an investment that is attractive to the investor. According to Richmond (1985), a prudent investor will consider the alternative type of investment available to him by comparing its qualities with that of an ideal investment. Though generally considered as risk elements, those factors found to determine the yields expected from real estate investment include security of capital, security and regularity of income, management potential and transfer of ownership of property.Taking into consideration the various stages involved in real estate development, it became pertinent to sample the opinions of property investors. The result is shown on Table 2 below.

Table 2: Risk Elements in Relation to Stages of Real Estate Development

\begin{tabular}{|l|l|l|l|}
\hline S/N & RISK ELEMENTS & RESPONSE RATE & \% of RESPONSE \\
\hline 1 & Identification of actual land owner & 10 & 5.3 \\
\hline 2 & Compliance to Zoning Policy & 9 & 4.8 \\
\hline 3 & Adherence to Planning Specifications & 13 & 6.9 \\
\hline 4 & Delay Issuance of C-of-O & 22 & 11.7 \\
\hline 5 & Poor access to Project Site & 13 & 6.9 \\
\hline 6 & Non-availability of Basic infrastructure & 17 & 9.0 \\
\hline 7 & Hostility of Host Community & 14 & 7.5 \\
\hline 8 & Lack of Access to Project Finance & 25 & 13.3 \\
\hline 9 & Incompetent Building Contractor & 18 & 9.6 \\
\hline 10 & Use of Inferior Building materials & 12 & 6.4 \\
\hline 11 & Lack of Maintenance & 16 & 8.5 \\
\hline 12 & Default in Rent Payment & 19 & 10.1 \\
\hline Total & & $\mathbf{1 8 8}$ & $\mathbf{1 0 0}$ \\
\hline
\end{tabular}

Results indicated that lack of access to finance when needed and in adequate amount constitute the major risk encountered by real estate investor in the study area as shown by 25 respondents representing $13.3 \%$ of the sampled size. This was closely followed by delay in signing and issuance of Certificate of Occupancy by the state governor and statutory agency as shown by 22 respondents representing $11.7 \%$. Another risk faced by investors in real estate was seen to be default in rent payment by lease holders and other classes of occupiers of developed properties. This was the response by 19 respondents which represented $10.1 \%$ of the sampled size. 
The use of incompetent building contractors who could not interpret building plans and non-availability of basic infrastructure to ease the building process were noted as the $4^{\text {th }}$ and $5^{\text {th }}$ elements of risk encountered by real estate investors as indicated by 18 respondents and 17 respondents representing $9.6 \%$ and $9.0 \%$ respectively.

\subsection{Implications Of Risk Elements On Real Estate Investment In Urban Nigeria}

Risk has been seen as a common feature of all forms of investment in many urban centres in Nigeria. One fundamental problem of real estate investment is how investment decision can be taken without determining the extent of risk involved in the envisaged project. Thus, many rational investors do not take any investment decisions without a careful examination, identification and assessment of the expected risk elements. This is because an investor who embarks on a project of any type expects some benefits in the form of returns which are uncertain. These benefits are subjected to the effects of risk elements including the risk of being duped by fake property agents, non-compliance to planning and building regulations, lack of basic infrastructure at many project sites, inaccessibility to project finance, non-usage of durable building materials and competent contractors, lack of building maintenance and default in rent payment by occupiers of the property as listed on Table 2.It is common to also mention that the actual returns from any investment usually vary with individual project based on investors and analysts' projections. According to Nwokenkwo (2014), an investment is considered risky because the investor is unsure of the actual returns which he will realize from his investment. The degree of variability of the actual return from the estimated return of investment as well as the possibility of loss of capital reflects the risk elements of investment (Ubom, 2010). This clearly indicated that where the degree of variability is higher, the risk involved in the investment is certainly higher and vice versa. It has been observed that the influence of risk on real estate investment have forced many property investors to adopt wrong development strategies which result in poor construction leading to collapse of several buildings and structures in different urban centres of Nigeria.

\section{Conclusion And Recommendations}

Risk is a major factor that must be considered while embarking on any type of real estate investment. The influence of risk elements in real estate investment changes in the course of project development and in the life of many projects, especially as a consequence of site topography, planning policies, fiscal policies, building materials and technology, and the state of the national economy. An ideal real estate investor considers price certainty as an important economic variable since every risk element has direct or indirect effects on the financial budget of the project from conception to delivery or occupation. Even though many property investors consider risk, they do so intuitively or by simply demanding a higher return from their investment, amidst difficulty of predicting the future performance of their chosen investment. Therefore, real estate investors, appraisers and managers require effective and efficient risk management strategies to be able to study the development trend in real estate market that would in turn enable them to properly articulate and advice potential investors to identify investment outlets and their investment outcomes.

\section{References}

[1]. Ajayi, C.(1998). Property Investment Valuation and Analysis.Ibadan: De-Ayo Publications

[2]. Ajayi, C. (2010).Property Market Dynamics and Paradigm Shifts in Property Investment Valuation Methodology. Being Inaugural Lecture Series 234 delivered at ObafemiAwolowoUniversity, Ile Ife on Tuesday, October 26. Ile-Ife: ObafemiAwolowo University Press Limited

[3]. Barlowe, R. (1978). Land Resource Economics, $2^{\text {nd }}$ ed. New Jersey: Prentice-Hall Inc

[4]. Bowlin, O., Martin, J., \& Scott, D. (1980).Guide to Financial Analysis. New York: McGraw Hill Book Company

[5]. Chandra, P. (2010). Investment Analysis and Portfolio Management. New Delhi: Tata McGraw Hill Education Private Limited

[6]. Dubben, N. \&Sayce, S. (1991). Property Portfolio Management: An Introduction. London: Routledge

[7]. Emoh, F. (2004).Real Property Investment and Management.Awka: Christon International Company Limited

[8]. Enever, N. \&Isaac, D. (1997).The Valuation of Property Investment.London: The Estates Gazette Limited

[9]. Geddes, R. (2002). Valuation \& Investment Appraisal.Canterbury-Kent, United Kingdom: Financial World Publishing

[10]. Messner, S. (1984).Marketing Investment in Real Estate. Chicago: Realtor's National Marketing Institute

[11]. Nwokenkwo, B. (2014). Essentials of Real Estate Investment Appraisal.Minna: The Star Prints

[12]. Okafor,F. (1983).Investment Decision Evaluation of Projections and Sensitivities. London: Cassel Limited

[13]. Ubom, U. (2010). The Perspective of Risk Management: Domestic and International. Journal of Administrative Services 1(1): 172 184

[14]. Udoudoh, F. (2016).Real Estate and Infrastructure Economics in Urban Nigeria.Uyo, Nigeria: MEF Nigeria Limited 